\title{
INTS6 Gene
}

National Cancer Institute

\section{Source}

National Cancer Institute. INTS6 Gene. NCI Thesaurus. Code C24336.

This gene may play a role in the transcriptional regulation that modulates chondrogenesis. 